\title{
Udział mieszkańców w ustalaniu wydatków budżetu gminy w ramach tzw. budżetu partycypacyjnego (na przykładzie Torunia w latach 2013-2014)
}

\author{
Citizens' Participation in Planning Local Self-Government \\ Expenditures on the Example of the Participatory Budget \\ of the City of Torun in 2013 and 2014
}

Streszczenie. Budżet partycypacyjny, tworzony przy udziale obywateli współdecydujących o podziale części zasobów finansowych wspólnoty samorządowej, po raz pierwszy został opracowany w brazylijskim mieście Porto Alegre 25 lat temu. W krótkim czasie zyskał dużą popularność w Brazylii i innych krajach Ameryki Południowej. Ok. roku 2000 próby wdrażania budżetu partycypacyjnego podjęto w Europie (Wielka Brytania - 2000, Francja - 2002, Hiszpania - 2003). Pierwszym polskim miastem, które postanowiło rozdysponować część środków zgodnie z propozycjami zgłaszanymi przez mieszkańców, był w roku 2011 Sopot. Obecnie budżet partycypacyjny funkcjonuje w wielu polskich gminach, przede wszystkim miejskich. W artykule podjęta została próba określenia charakteru prawnego budżetu partycypacyjnego z punktu widzenia przepisów prawa, 
w szczególności zaś ustawy o samorządzie gminnym. Przedstawiono także konstrukcję prawną budżetu partycypacyjnego na przykładzie Torunia w latach 2013-2014.

Słowa kluczowe: budżet partycypacyjny; finanse publiczne; gmina.

\begin{abstract}
The idea of so-called participatory budget was brought into effect for the first time twenty five years ago in the Brazilian city of Porto Alegre. In the short time participatory budget gained a great popularity, spreading to the entire country, and then to other South-American states. About 2000 many cities all over the world made attempts to implement participatory budgets. Members of local communities usually are enthusiastic, as participatory budget empowers them to decide on part of expenditures of local self-governments. Participatory budget creates alternative way of spending public funds. In Poland, the first city that decided to implement participatory budget was Sopot (2011). At present participatory budget is functioning in several dozen Polish local self-government units. In the article author tries to explain role and position of participatory budget according to the Act on Local Self-Government (1991). The structure and procedure concerning participatory budget is described on the example of the city of Torun (2013-2014).
\end{abstract}

Keywords: participatory budget; public finance; local self-government units.

\title{
1. Wprowadzenie
}

Współuczestnictwo obywateli w procesie podejmowania decyzji dotyczących wspólnoty lokalnej stanowi wartość związaną z ideą samorządności. Aktywna postawa mieszkańców i ich zaangażowanie w sprawy gminy (np. poprzez przekazywanie informacji, opiniowanie proponowanych rozwiązań, uczestnictwo w konsultacjach) mogą przyczynić się do podnoszenia efektywności działań podejmowanych przez administrację samorządową ${ }^{1}$ Jednym z instrumentów tego współuczestnictwa, zdobywają-

J.A. Rybczyńska, Partycypacja obywatelska na poziomie lokalnym w III Rzeczypospolitej Polskiej - próba oceny, [w:] S. Michałowski (red.), Samorzq̨d terytorialny III Rzeczypospolitej. Dziesięć lat doświadczeń, Lublin 2002, s. 113-114. 
cym w ostatnich latach coraz większą popularność, jest tzw. budżet partycypacyjny.

Idea budżetowania partycypacyjnego narodziła się w Brazylii w latach 80. XX w. Jej powstanie wiązało się z demokratycznymi przemianami ustrojowymi, jakie wówczas zachodziły w tym państwie. Po raz pierwszy budżet partycypacyjny został opracowany w brazylijskim mieście Porto Alegre w 1989 r. Przygotowanie budżetu partycypacyjnego stanowiło inicjatywę oddolną (angażującą przede wszystkim wspólnoty sąsiedzkie oraz organizacje pozarządowe), która zyskała aprobatę władz miasta $^{2}$.

W kolejnych latach budżet partycypacyjny dynamicznie rozprzestrzeniał się po całym kraju, by wkrótce objąć swym zasięgiem inne państwa Ameryki Południowej. Ok. roku 2000 próby wdrażania budżetu partycypacyjnego podjęto w Europie (Wielka Brytania - 2000, Francja 2002, Hiszpania - 2003). Pierwszym polskim miastem, w którym pewną pulę środków budżetowych rozdysponowano na zasadach budżetowania partycypacyjnego, był w roku 2011 Sopot. Obecnie budżet partycypacyjny funkcjonuje w wielu polskich gminach, przede wszystkim miejskich. W Toruniu pilotażowy program budżetu partycypacyjnego zrealizowano w 2013 r.

Pojęcie budżetowania partycypacyjnego (participatory budgeting), jako metody służącej opracowaniu budżetu partycypacyjnego (participatory budget), nie zostało jak dotąd w sposób jednolity zdefiniowane w literaturze. Stawiane jest nawet pytanie, czy w przypadku budżetowania partycypacyjnego można w ogóle mówić o istnieniu uniwersalnej, dającej się porównywać konstrukcji ${ }^{3}$. Wynika to przede wszystkim z faktu, iż w różnych krajach pod pojęciem „budżetowania partycypacyjnego” funkcjonuje wiele odmiennych rozwiązań, procedur i instytucji ${ }^{4}$.

2 Zob. E. Ganuza, E. Baiocchi, The Power of Ambiguity: How Participatory Budgeting Travels the Globe, „Journal of Public Deliberation” 2012, vol. 8, issue 2, art. 8, s. 2 i n.

3 Y. Sintomer, C. Herzberg, A. Rőcke, Participatory Budgeting in Europe: Potentials and Challenges, „International Journal of Urban and Regional Research”, vol. 32.1, March 2008, s. 166, DOI: http://dx.doi.org/10.1111/j.1468-2427.2008.00777.x

4 Y. Sintomer, C. Herzberg, A. Rőcke, G. Allegretti, Transnational Models of Citizen Participation: The Case of Participatory Budgeting, „Journal of Public Deliberation” 
Przykładowo, według Briana Wamplera, budżetowanie partycypacyjne to proces decyzyjny, w którym obywatele dyskutują i negocjują nad sposobem dystrybucji zasobów publicznych ${ }^{5}$. Bardziej rozbudowaną definicję przedstawił Benjamin Goldfrank. Zgodnie z nią budżetowanie partycypacyjne to proces otwarty dla każdego obywatela, który zechce w nim uczestniczyć, łączący w sobie formy demokracji pośredniej i bezpośredniej, wymagający podjęcia dyskusji (nie zaś wyłącznie przeprowadzenia konsultacji), służący redystrybucji zasobów, którego zasady pomagają formułować sami uczestnicy, włączając w to określenie kryteriów alokacji zasobów ${ }^{6}$.

Pomimo istotnego zróżnicowania poszczególnych rozwiązań obejmowanych wspólnym pojęciem budżetowania partycypacyjnego, wyróżnia się kilka zasadniczych elementów wspólnych, którymi powinien cechować się proces tworzenia budżetu partycypacyjnego. Należą do nich w szczególności: konieczność przeprowadzenia wśród członków wspólnoty samorządowej szerokiej debaty publicznej dotyczącej podziału ograniczonych zasobów finansowych (przy zaangażowaniu organów administracji samorządowej), powtarzalność procesu w kolejnych latach budżetowych oraz istnienie określonych obowiązków sprawozdawczych odnośnie sposobu wydatkowania środków ${ }^{7}$.

Do najczęściej wymienianych w literaturze zalet budżetu partycypacyjnego należą: aktywizacja lokalnych społeczności i wzrost poczucia odpowiedzialności mieszkańców za sprawy dzielnicy, osiedla czy miasta (tworzenie społeczeństwa obywatelskiego), demokratyzacja procesu decyzyjnego, nawiązanie dialogu i współpracy między mieszkańcami, organizacjami pozarządowymi i urzędnikami ${ }^{8}$.

2012, vol. 8, issue 2, art. 9, s. 2. Zob. także Y. Cabannes (red.), 72 Frequently Asked Questions about Participatory Budgeting, Quito 2004, s. 20.

5 B. Wampler, A Guide to Participatory Budgeting, [w:] A. Shah (red.), Participatory Budgeting, Washington 2007, s. 21.

6 B. Goldfrank, Lessons from Latin America's Experience with Participatory Budgeting. History of Participatory Budgeting, [w:] A. Shah (red.), Participatory Budgeting, Washington 2007, s. 92.

7 Y. Sintomer, C. Herzberg, A. Rőcke, Participatory Budgeting in Europe..., s. 168.

8 W. Kębłowski, Budżet partycypacyjny. Krótka instrukcja obsługi, Warszawa 2013, s. 14. 
Wśród głównych ograniczeń wiążących się ze stosowaniem budżetu partycypacyjnego wskazuje się na brak głębszego zainteresowania mieszkańców poznaniem mechanizmów rządzących finansami lokalnymi, także w kontekście gromadzonych przez samorząd dochodów. Nadmierna koncentracja na realizacji drobnych projektów infrastrukturalnych w najbliższym otoczeniu może zaś skutkować brakiem szerszego zainteresowania sprawami publicznymi, zwłaszcza gdy wnioskowane zadania zostaną już zrealizowane. Ponadto instrument ten nie nadaje się do finansowania inwestycji wieloletnich ${ }^{9}$.

Celem artykułu jest próba określenia charakteru prawnego tzw. budżetu partycypacyjnego z punktu widzenia przepisów prawa, zwłaszcza ustawy o samorządzie gminnym ${ }^{10}$. Przedstawiono także konstrukcję prawną budżetu partycypacyjnego na przykładzie Torunia w latach 2013-2014 .

\section{Budżet partycypacyjny w świetle przepisów ustawy o samorządzie gminnym}

Jednostki samorządu terytorialnego (gminy) realizują zadania należące do zakresu ich działania, wynikające z przepisów u.s.g. oraz ustaw szczegółowych. Składają się na nie zadania własne (w tym o charakterze obowiązkowym) oraz zlecone ustawowo lub na podstawie zawartych porozumień. Wydatki ponoszone na realizację zadań nałożonych na samorząd gminny w drodze ustaw mają charakter wydatków sztywnych (gmina nie może z nich zrezygnować), a ich wysokość nie może być kształtowana w sposób dowolny. Są to przede wszystkim wydatki bieżące budżetu gminy, przeznaczone np. na utrzymanie placówek oświatowych czy pomoc społeczną. Fakt, iż wydatki na określone cele są zdeterminowane ustawowo (samorząd ma obowiązek ich ponoszenia), wyłącza współdecydowanie przez mieszkańców gminy o ich wysokości czy zasadności pono-

\footnotetext{
B. Wampler, A Guide to Participatory Budgeting..., s. 45 i n. Ustawa z dnia 8 marca 1990 r. o samorządzie gminnym (tekst jedn. Dz.U. z 2013 r.,
poz. 594 ze zm.), dalej: u.s.g.
} 
szenia ${ }^{11}$. W związku z tym należy zauważyć, że budżetowanie partycypacyjne będzie mogło odnosić się głównie do wydatków o charakterze majątkowym (inwestycyjnym), w przypadku których gmina posiada szerokie możliwości decyzyjne.

Przyjęta przez organ stanowiący gminy uchwała budżetowa stanowi podstawę prawną i upoważnienie do prowadzenia gospodarki finansowej gminy $\mathrm{w}$ danym roku budżetowym ${ }^{12}$. Zarówno ustawa samorządowa (u.s.g.), jak i przepisy u.f.p. w żaden sposób nie odnoszą się do udziału mieszkańców w procedurze konstruowania budżetu gminy i współdecydowania o przeznaczeniu jej zasobów finansowych. Pełnię kompetencji w tym zakresie ustawy powierzają organom gminy - wójtowi (burmistrzowi, prezydentowi) oraz radzie. Organ wykonawczy opracowuje projekt budżetu i przedkłada go radzie w terminie określonym w u.f.p. (do 15 listopada roku poprzedzającego rok budżetowy). Zgodnie zaś z art. 18 ust. 2 pkt 4 u.s.g. do wyłącznej właściwości rady gminy należy uchwalanie budżetu gminy, rozpatrywanie sprawozdania z jego wykonania oraz podejmowanie uchwały w przedmiocie udzielenia absolutorium $\mathrm{z}$ tego tytułu. Przepisy samorządowej procedury budżetowej nie dostarczają zatem wyraźnych podstaw do prowadzenia prac nad tzw. budżetem partycypacyjnym.

Ustawa o samorządzie gminnym w art. 5a ust. 1 stanowi, że w wypadkach przewidzianych ustawą oraz w innych sprawach ważnych dla gminy mogą być przeprowadzane na jej terytorium konsultacje z mieszkańcami. W przypadku opracowywania projektu budżetu gminy przepisy nie przewidują obowiązku wydzielenia określonej puli środków finansowych i przeprowadzenia konsultacji odnośnie sposobu jej wykorzystania. Wydaje się jednak, że konsultacje takie mogą zostać przeprowadzone fakultatywnie, gdyż zagadnienia związane z budżetem, stanowiącym podstawę gospodarki finansowej gminy w danym roku, wyczerpują znamiona

11 W przypadku zadań finansowanych za pomocą subwencji i dotacji z budżetu państwa możliwość decydowania przez gminę o zmianie przeznaczenia tych środków w ogóle nie występuje.

12 A. Borodo, Samorzqd terytorialny. System prawnofinansowy, wyd. 6, Warszawa 2008, s. 242. 
ustawowego pojęcia „sprawy ważnej dla gminy”. Podkreślić jednak należy, że przeprowadzenie konsultacji w sprawie wykorzystania części zasobów finansowych gminy nie ma charakteru obligatoryjnego i zależy od decyzji organów gminy. Wynik konsultacji nie jest zaś prawnie wiążący, choć stanowi istotny argument za przyjęciem rozwiązań postulowanych przez mieszkańców.

Konsultacje społeczne dotyczące tzw. budżetu partycypacyjnego dają mieszkańcom możliwość wypowiedzenia się w przedmiocie propozycji wydatkowania części środków przewidzianych w budżecie gminy na wskazane przez nich zadania inwestycyjne, remontowe lub inne. Zadania te mogą mieć charakter lokalny, ograniczony terytorialnie do danego osiedla czy dzielnicy lub obejmować obszar całej gminy (miasta) i dotyczyć spraw istotnych z punktu widzenia ogółu mieszkańców. Wynik konsultacji społecznych nie przesądza jednak o obowiązku realizacji zaproponowanych zadań.

W tym kontekście należy podkreślić, że tzw. budżet partycypacyjny nie stanowi samodzielnego planu finansowego, dotyczącego środków wyodrębnionych z zasobów gminy i niezależnych od jej budżetu. Jest to w istocie plan podziału pewnej kwoty, uwzględnionej w budżecie gminy, co do przeznaczenia której mieszkańcy mają możliwość wypowiedzenia się, zwykle w formie konsultacji społecznych. Konstruowanie budżetu partycypacyjnego jako odrębnego, niezależnego budżetu opartego na decyzjach podjętych przez mieszkańców gminy, który funkcjonowałby równolegle do budżetu gminy uchwalonego przez organ stanowiący, nie znajduje żadnego umocowania ani w przepisach samorządowego prawa budżetowego, ani w przepisach prawa o ustroju samorządu terytorialnego. Ponadto istnienie tego rodzaju dodatkowego budżetu stałoby w sprzeczności z zasadami jedności oraz zupełności budżetu ${ }^{13}$.

Współdecydowanie przez mieszkańców gminy o sposobie wykorzystania części środków budżetowych może być realizowane także za po-

13 Szerzej na temat roli i znaczenia tych zasad zob. A. Borodo, Samorzqd terytorialny..., s. 248-249. 
mocą funduszu sołeckiego ${ }^{14}$, który wykazuje pewne podobieństwa do konstrukcji budżetu partycypacyjnego. O wyodrębnieniu w budżecie gminy środków stanowiących fundusz sołecki decyduje rada, podejmując stosowną uchwałę do 31 marca roku poprzedzającego rok budżetowy. Kwota przypadająca na dane sołectwo obliczana jest na podstawie wzoru określonego w art. 3 ustawy o funduszu sołeckim. Środki funduszu mogą zostać przeznaczone na realizację przedsięwzięć należących do zadań własnych gminy, służących poprawie warunków życia mieszkańców i pozostających w zgodzie ze strategią rozwoju gminy. Wnioski dotyczące zadań przeznaczonych do realizacji w ramach funduszu sołeckiego uchwalane są przez zebrania wiejskie (w sołectwach), a następnie przekazywane wójtowi. Uprawnienie zebrania wiejskiego do samodzielnego wskazania przedsięwzięć, które miałyby zostać sfinansowane ze środków funduszu stanowi formę partycypacji obywatelskiej w zakresie planowania wydatków budżetowych gminy ${ }^{15}$.

14 Ustawa z dnia 21 lutego 2014 r. o funduszu sołeckim (Dz.U., poz. 301). Fundusz ten funkcjonuje w gminach wiejskich.

15 K. Bandarzewski, Opinia prawna dotyczqca prawnych uwarunkowań udziału społeczności lokalnych $w$ procesie konstruowania $i$ wykonywania budżetu gminy, s. 3, http://www.maszglos.pl/wp-content/uploads/2013/09/Ekspertyza-dotyczaca-budzetowobywatelskich-dr-K.Bandarzewski-.pdf (dostęp: 21 lutego 2014 r.). W dalszej części ekspertyzy autor przedstawia także propozycję ustawy „o funduszu jednostki pomocniczej”, która miałaby w kompleksowy sposób uregulować tworzenie funduszy wzorowanych na funduszu sołeckim także w gminach miejskich (zalety ujęcia zasad konstruowania budżetu partycypacyjnego w ramy ustawowe wymienia D. Sześciło, Uwarunkowania prawne budżetu partycypacyjnego w Polsce, „Finanse Komunalne” 2012, $\mathrm{nr}$ 12, s. 23). Na temat możliwości wykorzystania konstrukcji funduszu sołeckiego przy opracowywaniu budżetów partycypacyjnych zob. również R. Trykozko, Ekspertyza prawna dotyczqca uwarunkowań funkcjonowania budżetu obywatelskiego w miastach i zakresu możliwości przyznania miejskim jednostkom pomocniczym uprawnień do określania finansowanych z budżetu zadań w sposób wiq̨żący organy gminy, na zasadach zbliżonych do funduszu sołeckiego, http://funduszesoleckie.pl/wwwdane/files/ ekspertyza budzet_obywatelski_oskj.pdf (dostęp: 21 lutego 2014 r.). 


\section{Pilotażowy program budżetu partycypacyjnego w Toruniu w 2013 r.}

Przygotowania do wdrożenia budżetu partycypacyjnego w Toruniu przeprowadzono w formie pilotażowego programu, w ramach którego mieszkańcy mogli dokonać wyboru zadań przeznaczonych do realizacji aż do wyczerpania ustalonego limitu środków. W uchwale budżetowej na rok 2013 zostały zarezerwowane na ten cel $2 \mathrm{mln} \mathrm{zł}^{16}$. Głównym założeniem programu było wypracowanie odpowiednich procedur oraz zebranie doświadczeń wspomagających konstruowanie budżetu partycypacyjnego w kolejnych latach budżetowych.

Podział środków dokonany został zgodnie z zasadami przeprowadzenia konsultacji dotyczących pilotażu budżetu partycypacyjnego w Toruniu w roku 2013, określonymi w załączniku nr 1 do zarządzenia nr 79 Prezydenta Miasta Torunia z dnia 10 kwietnia 2013 r. $^{17}$ oraz uchwałą nr 508/2013 Rady Miasta Torunia z dnia 21 lutego 2013 r. w sprawie Regulaminu Konsultacji Społecznych ${ }^{18}$.

Lista zadań inwestycyjnych zaproponowanych do realizacji została utworzona z uwzględnieniem wniosków zgłaszanych przez mieszkańców, Rady Okręgów, radnych oraz organizacje pozarządowe do projektów

16 Zob. załącznik nr 8 (Toruń gmina i powiat, plan inwestycyjny na rok 2013 oraz wynikające z niego nakłady na wieloletnie programy inwestycyjne) do uchwały nr 456/12 Rady Miasta Torunia z dnia 13 grudnia 2012 r. w sprawie budżetu miasta na rok 2013 (Dz.Urz. Woj. Kujawsko-Pomorskiego, poz. 3792 ze zm.). Środki te zostały sklasyfikowane w dziale 900 Gospodarka komunalna i ochrona środowiska, rozdziale 90095 Pozostała działalność.

17 Zarządzenie nr 79 Prezydenta Miasta Torunia z dnia 10 kwietnia 2013 r. w sprawie konsultacji społecznych dotyczących pilotażu budżetu partycypacyjnego w Toruniu w roku 2013, http://www.bip.torun.pl/files/doc/z_79_2013_01.pdf (dostęp: 11 stycznia 2014 r.). Zasady te opracował zespół doradczy, w skład którego weszli m.in. Skarbnik Miasta Torunia, przedstawiciele radnych Rady Miasta Torunia, rad okręgów i organizacji pozarządowych - zob. zarządzenie nr 4 Prezydenta Miasta Torunia z dnia 9 stycznia 2013 r. w sprawie powołania zespołu doradczego ds. opracowania propozycji modelu budżetu partycypacyjnego dla Torunia, http://www.bip.torun.pl/files/ doc/z_4_2013_01.pdf (dostęp: 11 stycznia 2014 r.).

18 Uchwała nr 508/2013 Rady Miasta Torunia z dnia 21 lutego 2013 r. w sprawie Regulaminu Konsultacji Społecznych (ze zm.), http://www.bip.torun.pl/files/doc/ 508_13_zal_01.pdf, (dostęp: 11 stycznia 2014 r.). 
uchwał budżetowych na lata 2012 i 2013, wniosków sformułowanych przez mieszkańców podczas spotkań z Prezydentem Miasta oraz w trakcie bieżących prac miejskich jednostek organizacyjnych ${ }^{19}$. O umieszczeniu zadania na liście decydowała także możliwość jego realizacji do dnia 31 grudnia 2013 r. oraz posiadanie przez jednostki organizacyjne gminy gotowej dokumentacji projektowej lub możliwość jej wykonania wraz z rzeczową realizacją zadania przed końcem roku budżetowego. Szacunkowa wartość pojedynczego zadania umieszczonego na liście nie mogła przekroczyć 33\% kwoty wydzielonej w budżecie miasta na realizację pilotażu budżetu partycypacyjnego.

Lista zadań została podana do publicznej wiadomości m.in. w punktach informacyjnych Urzędu Miasta Torunia oraz na stronie internetowej $^{20}$. Pod głosowanie mieszkańców poddanych zostało 28 projektów $^{21}$ o łącznej szacunkowej wartości kosztorysowej 5 mln 570 tys. zł.

Zgodnie z §3 ust. 3 załącznika udział w głosowaniu mogła wziąć każda osoba fizyczna, która ukończyła 16. rok życia (liczony wg daty urodzenia) i mająca miejsce zamieszkania w Toruniu. Pojęcie „miejsca zamieszkania” zostało określone poprzez odwołanie się do definicji zawartych w Kodeksie cywilnym ${ }^{22}$ oraz ustawie o podatku dochodowym od osób fizycznych ${ }^{23}$. Miejsca zamieszkania nie należy utożsamiać z administracyjnoprawną kategorią meldunku, określoną w ustawie o ewidencji ludności i dowodach osobistych ${ }^{24}$ (choć dopełnienie obowiązku meldunkowego powinno być konsekwencją stanu wynikającego z art. 25 k.c.).

\footnotetext{
Załącznik nr 2 do zarządzenia z 10 kwietnia 2013 r.

http://www.torun.pl/2miliony (dostęp: 11 stycznia 2014 r.)

21 Zdecydowaną większość stanowiły projekty dotyczące infrastruktury drogowej budowy lub remontów dróg gminnych, chodników, sygnalizacji świetlnej, miejsc parkingowych dla samochodów i rowerów (20), następnie zaś infrastruktury sportowej i rekreacyjnej - budowa placów zabaw oraz ścieżek rekreacyjnych (4) oraz zieleni miejskiej (4).

22 Ustawa z dnia 23 kwietnia 1964 r. Kodeks cywilny (tekst jedn. Dz.U. z 2014 r., poz. 121), dalej: k.c.

23 Ustawa z dnia 26 lipca 1991 r. o podatku dochodowym od osób fizycznych (tekst jedn. Dz.U. z 2012 r., poz. 361 ze zm.).

24 Zob. art. 4-14 ustawy z dnia 10 kwietnia 1974 r. o ewidencji ludności i dowodach osobistych (tekst jedn. Dz.U. z 2006 r. Nr 139, poz. 993 ze zm.).
} 
Odpowiednie zastosowanie art. 3 ust. 1a ustawy o podatku dochodowym od osób fizycznych, w świetle zasad określonych w zarządzeniu nr 79, przez mieszkańców Torunia nakazuje rozumieć także osoby, które posiadają w mieście ośrodek interesów osobistych lub gospodarczych (ośrodek interesów życiowych) lub przebywają w nim dłużej niż 183 dni w roku. Dotyczy to zwłaszcza więzi wyrażających się poprzez pobieranie nauki, zatrudnienie lub prowadzenie działalności gospodarczej, a niekoniecznie fakt zamieszkiwania.

Głosowanie na projekty wskazane w ramach programu pilotażowego polegało na wypełnieniu ankiety w formie papierowej lub elektronicznej, z podaniem na niej adresu zamieszkania i numeru PESEL osoby oddającej głos. Głosowanie odbywało się w dniach 12-30 kwietnia 2013 r. Głosujący mógł wybrać maksymalnie 3 zadania z listy zaproponowanych projektów. W głosowaniu udział wzięło 3312 osób (złożono 1298 ankiet papierowych, a 2014 przesłano drogą elektroniczną). 124 ankiety okazały się nieważne. Na wszystkie projekty prawidłowo oddano 5704 głosy.

Do realizacji zostało przyjętych osiem projektów, które uzyskały kolejno największą liczbę głosów, aż do wyczerpania puli dostępnych środków ${ }^{25}$.

Tabela 1. Wykaz zadań przyjętych do realizacji w ramach programu pilotażu budżetu partycypacyjnego w Toruniu w $2013 \mathrm{r}$.

\begin{tabular}{|r|l|c|c|}
\hline Lp. & \multicolumn{1}{|c|}{ Projekt (zadanie) } & $\begin{array}{c}\text { Liczba } \\
\text { głosów }\end{array}$ & Szacunkowy koszt \\
\hline 1. & $\begin{array}{l}\text { Budowa placu zabaw przy SP nr 2 } \\
\text { (ul. Targowa 17) }\end{array}$ & 997 & $200000 \mathrm{zł}$ \\
\hline 2. & Budowa odcinka ul. Przylaszczkowej & 495 & $650000 \mathrm{zł}$ \\
\hline 3. & $\begin{array}{l}\text { Budowa zewnętrznych siłowni sportowych } \\
\text { w fosie zamkowej przy teatrze Baj Pomorski }\end{array}$ & 436 & $30000 \mathrm{zł}$ \\
\hline 4. & Budowa odcinka ul. Przyjaciół & 335 & $570000 \mathrm{zł}$ \\
\hline
\end{tabular}

25 Zadania te zostały umieszczone na liście podstawowej. Kolejne zadania, wg uzyskanej liczby głosów, trafiły na listę rezerwową, z możliwością realizacji w przypadku uzyskania oszczędności przetargowych na zadania z listy podstawowej. Lista zadań przyjętych do realizacji została ogłoszona 10 maja 2013 r. na stronie internetowej oraz w siedzibie Urzędu Miasta Torunia. 


\begin{tabular}{|r|l|c|c|}
\hline 5. & $\begin{array}{l}\text { Budowa ścieżki rekreacyjnej w parku Glazja } \\
\text { (ul. Waryńskiego) }\end{array}$ & 334 & $40000 \mathrm{zł}$ \\
\hline 6. & $\begin{array}{l}\text { Remont odcinka ul. Rolniczej i łącznika do } \\
\text { ul. Polnej }\end{array}$ & 307 & $400000 \mathrm{zł}$ \\
\hline 7. & Budowa placu zabaw przy ul. Zbożowej & 282 & $50000 \mathrm{zł}$ \\
\hline 8. & Montaż sygnalizacji świetlnej przy ul. Chrobrego & 270 & $70000 \mathrm{zł}$ \\
\hline \multicolumn{2}{|r|}{ Razem lista podstawowa } & 3456 & $2010000 \mathrm{zł}^{26}$ \\
\hline
\end{tabular}

Źródło: Sprawozdanie z przebiegu konsultacji społecznych dotyczących pilotażu budżetu partycypacyjnego w Toruniu w 2013 r. Zestawienie wyników głosowania wg liczby oddanych głosów, http://www.konsultacje.torun.pl/sites/default/files/ pictures/Dokumenty/budzet_party_2013_tabela_2_wg_glosow.pdf

(dostęp: 11 stycznia 2014 r.).

\section{Budżet partycypacyjny Miasta Torunia na rok 2014}

Pilotażowy program budżetu partycypacyjnego spotkał się z pozytywnym przyjęciem ze strony mieszkańców Torunia. Doświadczenia zgromadzone podczas jego realizacji zostały wykorzystane podczas prac nad regulaminem, służącym do opracowania budżetu partycypacyjnego na rok 2014 i w latach następnych. 21 listopada 2013 r. Rada Miasta Torunia przyjęła uchwałę nr 655/2013 w sprawie budżetu partycypacyjnego w Toruniu

26 Po dokonaniu przez mieszkańców wyboru zadań do realizacji, zadania te zostały zapisane w odpowiednich rozdziałach klasyfikacji budżetowej (początkowo łączna kwota 2 mln zł przeznaczona na pilotaż budżetu partycypacyjnego została ujęta jako wydatki inwestycyjne w rozdziale 90095). Remont odcinka ul. Rolniczej i łącznika do ul. Polnej przeniesiony został do wydatków bieżących - remonty (rozdział 60016). Pozostałe zadania zostały zaklasyfikowane do wydatków inwestycyjnych: budowa ścieżki rekreacyjnej (rozdział 63095), budowa placu zabaw przy SP 2 (rozdział 80101), budowa placu zabaw przy ul. Zbożowej (rozdział 90095), budowa zewnętrznych siłowni sportowych (rozdział 92695). Budowa odcinków ulic: Przylaszczkowej i Przyjaciół oraz montaż sygnalizacji świetlnej przy ul. Chrobrego ujęte zostały w ramach jednego zadania pod nazwą „budowa dróg lokalnych i infrastruktury” (rozdział 60016), a łączny ich koszt został ponownie oszacowany i pomniejszony o 10 tys. zł. Zob. uchwała $\mathrm{nr}$ 555/13 Rady Miasta Torunia z dnia 20 czerwca 2013 r. zmieniająca uchwałę w sprawie budżetu miasta na rok 2013, s. 41, http://www.bip.torun.pl/files/doc/ 555_13_zal_01.pdf (dostęp: 11 stycznia 2014 r.). 
oraz w sprawie zmiany Regulaminu Konsultacji Społecznych ${ }^{27}$ wraz $^{2}$ z załącznikiem w postaci Regulaminu budżetu partycypacyjnego w Toru$\mathrm{niu}^{28}$.

Zgodnie z §2 uchwały na budżet partycypacyjny przeznacza się nie mniej niż 6,0\% wykonanych dochodów Gminy Miasta Toruń z tytułu podatku od nieruchomości, przy czym do ustalenia tej kwoty przyjmuje się wartość podatku uzyskaną w roku poprzedzającym o dwa lata rok realizacji budżetu partycypacyjnego. Kwotę tę zaokrągla się do pełnych dziesiątek tysięcy złotych. Wykonany dochód Gminy Miasta Toruń z tytułu podatku od nieruchomości według stanu na dzień 31 grudnia 2012 r. wyniósł 107301412 zł ${ }^{29}$. W związku z tym wysokość środków przeznaczonych do wydatkowania w ramach budżetu partycypacyjnego w roku 2014 wynosi 6438 084,72 zł, co po zaokrągleniu daje kwotę 6440000 zł. Kwota ta została ujęta w części inwestycyjnej budżetu Miasta Torunia na rok 2014 w dziale 900 gospodarka komunalna i ochrona środowiska, rozdziale 90095 pozostała działalność ${ }^{30}$.

Określony w załączniku do uchwały nr 655/13 Regulamin budżetu partycypacyjnego określa terytorialny podział środków, zasady zgłaszania propozycji zadań, ich weryfikacji, sposób głosowania i obliczania wyników oraz harmonogram prac nad budżetem partycypacyjnym.

27 Uchwała nr 655/13 Rady Miasta Torunia z dnia 21 listopada 2013 r. w sprawie budżetu partycypacyjnego w Toruniu oraz w sprawie zmiany Regulaminu Konsultacji Społecznych, http://www.bip.torun.pl/files/doc/655_13_01.pdf (dostęp: 11 stycznia 2014 r.). W przypadku programu pilotażowego konsultacje społeczne przeprowadzane były zgodnie z postanowieniami przywoływanej już uchwały nr 508/13 Rady Miasta Torunia w sprawie Regulaminu Konsultacji Społecznych. Począwszy od roku 2014 uchwała ta nie znajduje zastosowania w przypadku konsultacji dotyczących budżetu partycypacyjnego, gdyż jej właściwość wyłączył §4 uchwały nr 655/13 RMT, stanowiący, iż „przepisów uchwały [w sprawie Regulaminu Konsultacji Społecznych przypis aut.] nie stosuje się do konsultacji, których zasady i tryb zostały uregulowane w odrębnej uchwale Rady Miasta Torunia”. http://www.bip.torun.pl/files/doc/655_13_zal_01.pdf (dostęp: 11 stycznia 2014 r.).

29 Zob. zarządzenie nr 77 Prezydenta Miasta Torunia z dnia 29 marca 2013 r. w sprawie sprawozdania z wykonania budżetu miasta za rok 2012, s. 9, http://www.bip.torun.pl/ files/dokumenty/wyk_budzetu_za_2012_sprawozdanie.pdf (dostęp: 11 stycznia 2014 r.).

30 Uchwała nr 672/13 Rady Miasta Torunia z dnia 19 grudnia 2013 r. w sprawie budżetu miasta na rok 2014 (Dz.Urz. Woj. Kujawsko-Pomorskiego z 2014 r., poz. 189). 
W świetle Regulaminu budżet partycypacyjny został zdefiniowany jako forma konsultacji społecznych w sprawie przeznaczenia części wydatków z budżetu Torunia na wskazane przez mieszkańców projekty mieszczące się $\mathrm{w}$ kompetencjach gminy ${ }^{31}$. Projekty te mogą obejmować zadania mieszczące się w kategorii zadań własnych gminy lub zadań własnych powiatu. Jednakże w świetle $\S 1 \mathrm{w}$ zw. z $\$ 13$ uchwały, w ramach procedury budżetowania partycypacyjnego nie mogą być realizowane zadania:

- których realizacja przekraczałaby wysokość środków dostępnych w ramach budżetu partycypacyjnego w danym roku na dany obszar (okręg dla zadań lokalnych, całe miasto w przypadku zadań ogólnomiejskich),

- które po zrealizowaniu generowałyby niewspółmiernie wysokie koszty utrzymania w stosunku do proponowanej wartości zadania,

- stojące w sprzeczności z obowiązującymi w mieście programami i planami, np. miejscowymi planami zagospodarowania przestrzennego czy wieloletnią prognozą finansową,

- wymagające współpracy instytucjonalnej podmiotów zewnętrznych, o ile te nie wyraziły w formie pisemnej oświadczenia o gotowości do podjęcia takiej współpracy,

- sprzeczne z przepisami prawa bądź naruszające prawa osób trzecich,

- obejmujące wyłącznie sporządzenie projektu bądź planu przedsięwzięcia,

- dla których przewidziane zostały jedynie środki na wykonanie, bez zabezpieczenia pokrycia kosztów projektowania.

Zgodnie z §2 uchwały zadania realizowane w ramach budżetu partycypacyjnego mogą mieć charakter lokalny lub ogólnomiejski. W związku z tym ogół środków dzielony jest na dwie pule - lokalną (70\%) i ogólnomiejską (30\%). Pula lokalna przeznaczona jest na realizację zadań służących mieszkańcom poszczególnych części miasta (okręgów), ustalonych w uchwale w sprawie powołania okręgów będących jednostkami pomoc-

31 Definicja ta w istocie odwołuje się do sposobu decydowania przez mieszkańców o podziale kwoty środków określanej w budżecie gminy mianem „,budżetu partycypacyjnego". 
niczymi Gminy Miasta Toruń oraz nadania im statutów ${ }^{32}$. Podział puli lokalnej dokonywany jest $\mathrm{w}$ oparciu o zasady określone w §4 ust. 3 uchwały. Zgodnie z nimi 50\% puli lokalnej dzielone jest w równych częściach pomiędzy poszczególne okręgi. 25\% puli dzielone jest proporcjonalnie do liczby mieszkańców poszczególnych okręgów, wg stanu na dzień 1 stycznia roku, w którym obliczana jest pula. Pozostałe 25\% środków dzielone jest natomiast proporcjonalnie do powierzchni okręgów.

Tabela 2. Podział środków z puli lokalnej w budżecie partycypacyjnym Torunia na 2014 r.

\begin{tabular}{|r|l|r|r|r|c|}
\hline Lp. & Okręg-osiedle & $\begin{array}{c}\text { Liczba } \\
\text { mieszkańców }\end{array}$ & $\begin{array}{c}\text { Powierz- } \\
\text { chnia }\left(\mathrm{m}^{2}\right)\end{array}$ & $\begin{array}{c}\text { Pula na okręg obli- } \\
\text { czona zgodnie z §4 } \\
\text { ust. 3 uchwały } \\
655 / 13 \mathrm{RMT}\end{array}$ & $\begin{array}{c}\text { \% puli } \\
\text { lokalnej }\end{array}$ \\
\hline 1. & Bydgoskie & 34278 & 22339638 & $585706 \mathrm{zł}$ & 12,99 \\
\hline 2. & $\begin{array}{l}\text { Jakubskie- } \\
\text { Mokre }\end{array}$ & 26700 & 16530713 & $486080 \mathrm{zł}$ & 10,78 \\
\hline 3. & Rubinkowo & 24972 & 2630319 & $371887 \mathrm{zł}$ & 8,25 \\
\hline 4. & Skarpa & 24845 & 5885157 & $357821 \mathrm{zł}$ & 7,94 \\
\hline 5. & Chełmińskie & 24418 & 4600744 & $356955 \mathrm{zł}$ & 7,92 \\
\hline 6. & Staromiejskie & 20678 & 2288354 & $345988 \mathrm{zł}$ & 7,67 \\
\hline 7. & Wrzosy & 11313 & 12339361 & $340919 \mathrm{zł}$ & 7,56 \\
\hline 8. & Podgórz & 10418 & 11646430 & $324659 \mathrm{zł}$ & 7,20 \\
\hline 9. & Grębocin & 7311 & 11269365 & $313185 \mathrm{zł}$ & 6,95 \\
\hline 10. & Stawki & 6010 & 6156270 & $280332 \mathrm{zł}$ & 6,22 \\
\hline
\end{tabular}

32 Uchwała nr 372/2012 Rady Miasta Torunia w sprawie powołania okręgów będących jednostkami pomocniczymi Gminy Miasta Toruń oraz nadania im statutów, http://www.bip.torun.pl/files/doc/372_12_01.pdf (dostęp: 11 stycznia 2014 r.). Zgodnie z uchwałą Toruń został podzielony na 13 okręgów z uwzględnieniem czynników takich jak: liczba ludności, zbliżony układ osadniczy i przestrzenny, więzi społeczne i gospodarcze, a także czynniki historyczne oraz granice naturalne, które wywarły wpływ na ukształtowanie się danej wspólnoty. 


\begin{tabular}{|r|l|c|c|c|c|}
\hline 11. & Czerniewice & 2625 & 4483413 & $267482 \mathrm{zł}$ & 5,93 \\
\hline 12. & Kaszczorek & 2375 & 5972140 & $245030 \mathrm{zł}$ & 5,44 \\
\hline 13. & Rudak & 2356 & 9609021 & $231956 \mathrm{zł}$ & 5,15 \\
\hline
\end{tabular}

Źródło: Materiały informacyjne Urzędu Miasta Torunia przedstawione 2 października 2013 r. na konferencji prasowej w sprawie budżetu partycypacyjnego Torunia na rok 2014, http://www.konsultacje.torun.pl/sites/default/files/pictures/Konsultacje/ bp_konf_pras_3-10-2013.pdf (dostęp: 11 stycznia 2014 r.).

Propozycje zadań do budżetu partycypacyjnego może zgłaszać każdy mieszkaniec Torunia, który w momencie wypełniania wniosku ma ukończone 16 lat. Pojęcie „mieszkańca” uchwała nr 655/13 definiuje w analogiczny sposób, jak w przypadku programu pilotażowego w roku 2013 (poprzez odwołanie do k.c. oraz ustawy o podatku dochodowym od osób fizycznych). Zadania o charakterze lokalnym dotyczące danego okręgu mogą zgłaszać tylko mieszkańcy tego okręgu. Kryterium właściwości terytorialnej nie obowiązuje w przypadku zgłaszania projektów o charakterze ogólnomiejskim. Każdy mieszkaniec może zgłosić maksymalnie dwie propozycje zadań do puli lokalnej oraz jedną do puli ogólnomiejskiej. Zgłaszający może przedstawić własne oszacowanie kosztów realizacji zadania, jednakże ostatecznej wyceny dokonuje prezydent miasta w procesie weryfikacji wniosków.

Do realizacji kierowane są te projekty, które uzyskały kolejno największą liczbę głosów aż do wyczerpania puli środków przewidzianych w danym roku w ramach budżetu partycypacyjnego. Jeżeli środki na realizację kolejnego zadania z listy nie będą wystarczające, uwzględnione zostanie pierwsze z następnych zadań na liście, którego realizacja nie spowoduje przekroczenia dostępnych w danym roku środków (§23 ust. 4 uchwały). Jeżeli zaś w toku realizacji projektów poczynione zostaną oszczędności (np. ceny określone w ofertach przetargowych będą niższe od założeń wynikających z kosztorysu), a pozostała kwota będzie wystarczająca do realizacji innych projektów, wykonane mogą być kolejne projekty z listy niezakwalifikowanych (w ramach właściwej puli - lokalnej lub ogólnomiejskiej), aż do ponownego wyczerpania środków (§24). 
Zgodnie z harmonogramem dla budżetu partycypacyjnego na rok 2014, mieszkańcy mogli składać wnioski w dniach od 26 listopada do 16 grudnia 2013 r. Złożonych zostało 215 propozycji, które poddano weryfikacji pod kątem spełniania wymogów formalnych. Na listach do głosowania znalazły się ostatecznie 144 projekty $^{33}$, w tym 28 w puli ogólnomiejskiej. Głosowanie przeprowadzono w dniach 25 stycznia - 3 lutego 2014 r. przy użyciu kart drukowanych oraz formularza internetowego. Każdy głosujący mógł poprzeć maksymalnie trzy projekty z jednej listy lokalnej (dotyczącej jednego okręgu) oraz trzy projekty z listy ogólnomiejskiej. W głosowaniu udział wzięło 22246 osób. Oddanych zostało 64785 ważnych głosów. Lista zwycięskich projektów ogłoszona została 14 lutego 2014 r. i objęła 43 zadania, w tym 2 o charakterze ogólnomiejskim. Podobnie jak w przypadku programu pilotażowego, największe poparcie uzyskały projekty związane z budową infrastruktury sportowej i rekreacyjnej oraz zadania z zakresu drogownictwa (zob. Tabela 3).

Terminy obowiązujące przy opracowywaniu budżetu partycypacyjnego na rok 2014 miały charakter wyjątkowy. Zgodnie bowiem z §27 uchwały, harmonogram prac nad budżetem partycypacyjnym w kolejnych latach będzie przedstawiał się następująco:

- $\quad$ podanie informacji na temat wysokości środków przewidzianych na danych rok w ramach budżetu partycypacyjnego: do 25 lutego ${ }^{34}$;

3318 zgłoszeń nie spełniało wymogów formalnych (w tym 15 zostało wycofanych przez zgłaszających), 7 projektów przekraczało dostępną pulę środków, 2 zostały połączone z innymi projektami poddanymi pod głosowanie, 11 zaproponowanych zadań zostało uwzględnionych do realizacji w budżecie miasta na rok 2014 lub przewidziane są do wykonania w latach kolejnych, 11 obejmowało działania nienależące do zakresu zadań własnych gminy/powiatu, w przypadku 8 projektów termin ich realizacji był przewidziany na okres przekraczający rok budżetowy. Pełna lista propozycji odrzuconych dostępna jest pod adresem http://www.torun.pl/sites/default/files/pictures/bp2014/ bp_2014_glosowanie_odrzuc.pdf (dostęp: 21 lutego 2014 r.).

W 2013 r. wykonane dochody Gminy Miasta Toruń z tytułu podatku od nieruchomości wyniosły 109719964 zł. W związku z tym, zgodnie z obliczeniami określonymi w uchwale nr 655/13 RMT, w 2015 r. w ramach budżetu partycypacyjnego została przewidziana do rozdysponowania kwota 6580000 zł, z czego 4606000 zł (70\%) przypada na pulę lokalną, zaś 1974000 zł (30\%) na pulę ogólnomiejską. Źródło: komunikat na stronie internetowej Urzędu Miasta Torunia z dnia 24 lutego 2014 r., http://www.torun.pl/pl/budzet-partycypacyjny-2015 (dostęp: 24 lutego 2014 r.). Zob. 
Tabela 3. Projekty wybrane przez mieszkańców Torunia do realizacji w ramach budżetu partycypacyjnego w $2014 \mathrm{r}$. wg kategorii ${ }^{35}$

\begin{tabular}{|r|l|c|c|c|}
\hline Lp. & \multicolumn{1}{|c|}{ Kategoria } & $\begin{array}{c}\text { Liczba } \\
\text { projektów }\end{array}$ & $\begin{array}{c}\text { \% } \\
\text { głosów }\end{array}$ & $\begin{array}{c}\text { Szacunkowy } \\
\text { koszt (zł) }\end{array}$ \\
\hline 1. & $\begin{array}{l}\text { Sport i rekreacja (place zabaw, siłow- } \\
\text { nie, boiska) }\end{array}$ & 23 & 53 & 4264000 \\
\hline 2. & $\begin{array}{l}\text { Infrastruktura drogowa (m.in. remonty } \\
\text { ulic, sygnalizacja) }\end{array}$ & 8 & 19 & 1538000 \\
\hline 3. & Wybiegi dla psów & 3 & 7 & 120000 \\
\hline 4. & Inne & 9 & 21 & 518000 \\
\hline
\end{tabular}

Źródło: Opracowanie własne na podstawie materiałów informacyjnych Urzędu Miasta Torunia, http://www.torun.pl/sites/default/files/pictures/bp_wyniki_glosowania_ 14-02-2014.pdf (dostęp: 21 lutego 2014 r.).

- $\quad$ składanie wniosków (propozycji zadań): od 1 do 31 marca;

- $\quad$ weryfikacja złożonych wniosków: do 31 maja;

- publikacja listy projektów, które zostaną poddane pod głosowanie mieszkańców: w terminie 5 dni od dnia zakończenia weryfikacji wniosków;

- głosowanie: do 30 czerwca;

- obliczanie oddanych głosów: do 15 lipca;

- ogłoszenie listy projektów, które uzyskały największą liczbę głosów i tym samym zostaną skierowane do realizacji: do 25 lipca - roku poprzedzającego rok, na który ustala się budżet partycypacyjny.

też zarządzenie nr 55 Prezydenta Miasta Torunia z dnia 26 marca 2014 r. w sprawie sprawozdania z wykonania budżetu miasta za rok 2013, http://www.bip.torun.pl/files/ dokumenty/spraw_z_wyk_bud_torunia_za_rok_2013.pdf (dostęp: 31 marca 2014 r.).

35 Pełny wykaz zadań wybranych przez mieszkańców do realizacji dostępny jest pod adresem http://www.torun.pl/sites/default/files/pictures/bp_2014_wyniki_komplet_ lista_ok.pdf (dostęp: 21 lutego 2014 r.). 


\section{Podsumowanie}

Instytucja tzw. budżetu partycypacyjnego, na świecie znana od ok. 25 lat, w Europie pojawiła się ok. roku 2000. Polskie doświadczenia w tej materii są skromne, pierwszy budżet partycypacyjny opracowano w 2011 r. Angażujące obywateli w proces zarządzania środkami publicznymi budżetowanie partycypacyjne jest uznawane za jedną $\mathrm{z}$ ważniejszych form uczestnictwa obywateli w życiu publicznym, jakie zostały wypracowane na przestrzeni ostatnich 20-30 lat ${ }^{36}$. W 1996 r. na szczycie w Stambule agenda Narodów Zjednoczonych UN-HABITAT ${ }^{37}$ określiła budżet partycypacyjny jako najlepszą z praktyk współczesnej demokracji lokalnej ${ }^{38}$.

Na gruncie prawa polskiego ogół kompetencji w zakresie przygotowywania projektu uchwały budżetowej, jej uchwalania, a następnie wykonywania należy do właściwych organów gminy (wójta, burmistrza bądź prezydenta miasta oraz rady). Zarówno w ustawie o samorządzie gminnym, jak i w ustawie o finansach publicznych brak jest regulacji prawnych odnoszących się do udziału mieszkańców w procesie konstruowania budżetu gminy.

Funkcjonujące w wielu polskich samorządach tzw. budżety partycypacyjne są w istocie jedną z pozycji wydatkowych zaplanowanych w budżecie gminy na dany rok. Nie stanowią odrębnego budżetu mogącego funkcjonować w sposób niezależny od budżetu gminy. Konstruowanie dodatkowego budżetu, o którego kształcie decydowaliby mieszkańcy wspólnoty samorządowej, pozbawione jest podstawy prawnej, a także stoi w sprzeczności z zasadami budżetowymi (jedności i zupełności).

Decydowanie mieszkańców o podziale części środków wydzielonych w odrębnym rozdziale w budżecie gminy jako „budżet partycypacyjny” opiera się zazwyczaj na mechanizmie konsultacji społecznych, które nie mają charakteru wiążącego. Zastosowanie w danej gminie instytucji tzw. budżetu partycypacyjnego jest fakultatywne i zależy od decyzji organów

36 Y. Sintomer, C. Herzberg, A. Rőcke, G. Allegretti, Transnational Models..., s. 1.

37 Program Narodów Zjednoczonych ds. Osiedli Ludzkich (United Nations Human Settlements Programme) - utworzona w 1978 r. agenda ONZ zajmująca się sprawami urbanizacji i osiedli ludzkich.

38

E. Ganuza, E. Baiocchi, The Power of Ambiguity..., s. 7. 
gminy. Organ wykonawczy na etapie przygotowywania projektu budżetu gminy nie jest prawnie zobligowany do wyodrębnienia po stronie wydatkowej środków na realizację budżetu partycypacyjnego. Podobnie organ stanowiący, uchwalając budżet, nie musi wyrazić zgody na taką formę współdecydowania mieszkańców o części wydatków budżetu gminy.

Wydatki w ramach budżetu partycypacyjnego mogą być dokonywane jedynie na cele mieszczące się w ustawowym zakresie zadań własnych gminy. Budżet partycypacyjny nie może kształtować tych wydatków, których obowiązek ponoszenia przez gminę oraz zasady ustalania ich wysokości wynikają z ustaw nakładających na samorząd obowiązek wykonywania określonych zadań.

W Toruniu wybór zadań, które zostaną zrealizowane ze środków budżetu partycypacyjnego, dokonywany jest w trybie konsultacji społecznych, określonym w uchwale Rady Miasta. Mieszkańcy mają możliwość zgłaszania propozycji zadań istotnych zarówno z perspektywy danego okręgu (lokalnych), jak i z perspektywy całego miasta, a następnie poparcia ich w głosowaniu. Realizowane są te projekty, które otrzymały największą liczbę głosów, aż do wyczerpania puli środków dostępnych w danym roku budżetowym.

\section{Bibliografia:}

Borodo A., Samorzq̨d terytorialny. System prawnofinansowy, LexisNexis, wyd. 6, Warszawa 2008.

Cabannes Y. (red.), 72 Frequently Asked Questions about Participatory Budgeting, UN-HABITAT (United Nations Human Settlements Programme), Quito 2004.

Ganuza E., Baiocchi E., The Power of Ambiguity: How Participatory Budgeting Travels the Globe, ,Journal of Public Deliberation” 2012, vol. 8, issue 2, art. 8, s. 1-14.

Goldfrank B., Lessons from Latin America's Experience with Participatory Budgeting. History of Participatory Budgeting, [w:] A. Shah (red.), Participatory Budgeting, The World Bank, Washington 2007.

Kębłowski W., Budżet partycypacyjny. Krótka instrukcja obsługi, Instytut Obywatelski, Warszawa 2013. 
Rybczyńska J.A., Partycypacja obywatelska na poziomie lokalnym w III Rzeczypospolitej Polskiej - próba oceny, [w:] S. Michałowski (red.), Samorzq̨d terytorialny III Rzeczypospolitej. Dziesięć lat doświadczeń, Lublin 2002, s. $113-120$.

Sintomer Y., Herzberg C., Rőcke A., Participatory Budgeting in Europe: Potentials and Challenges, „International Journal of Urban and Regional Research”, vol. 32.1, March 2008, DOI: http://dx.doi.org/10.1111/j.14682427.2008.00777.x, s. 164-178.

Sintomer Y., Herzberg C., Rőcke A., Allegretti G., Transnational Models of Citizen Participation: The Case of Participatory Budgeting, „Journal of Public Deliberation” 2012, vol. 8, issue 2, art. 9, s. 1-34.

Sześciło D., Uwarunkowania prawne budżetu partycypacyjnego w Polsce, „Finanse Komunalne” 2012, nr 12, s. 15-23.

Wampler B., A Guide to Participatory Budgeting, [w:] A. Shah (red.), Participatory Budgeting, The World Bank, Washington 2007. 